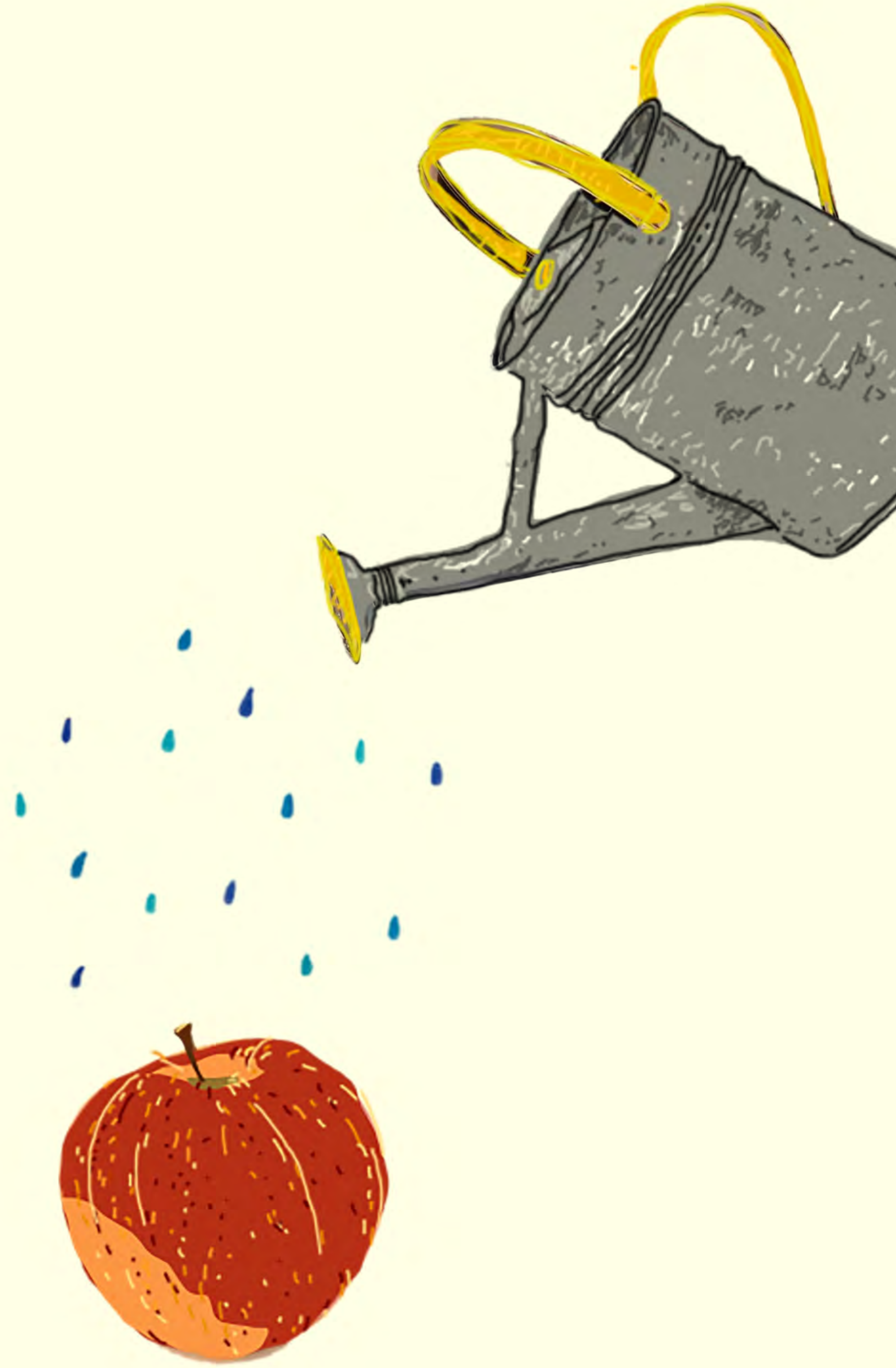




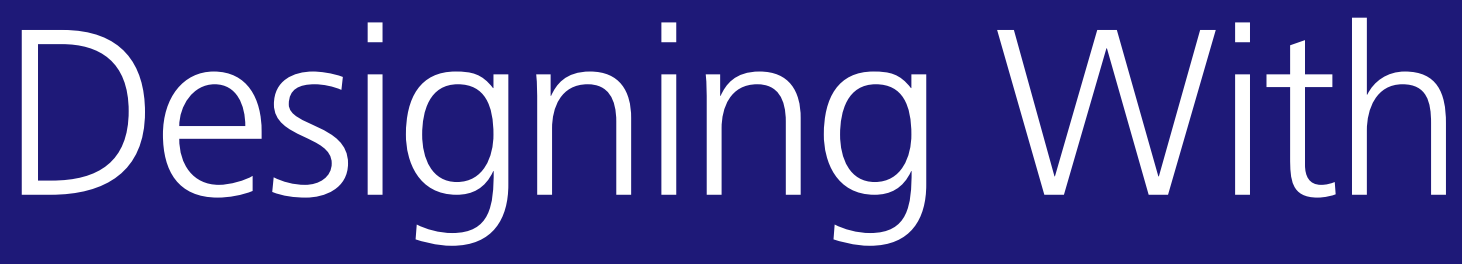

our Neighbors:

the CULTIVA Case

Paulina Cornejo Moreno Valle 


\section{Designing With our Neighbors: the CULTIVA Case}

\section{Paulina Cornejo Moreno Valle}

pcornejom@centro.edu,mx | CENTRO de diseño, cine y televisión, México.

Fecha de recepción: 20 de marzo de 2017 | Fecha de aceptación: 10 de mayo de 2018

\section{Abstract}

The paper seeks to contribute to the knowledge and research on how universities can use their resources to build bridges through design and social innovation with their surrounding communities. It is based on the case of the Social Design HUB of CENTRO University in Mexico City and its urban garden project CULTIVA, a joint initiative, based on transversal collaboration and the creation of shared value. The paper informs on the development of CULTIVA as an area for learning and social interaction in a neighborhood with a substantial decline in public space and community life, and shares findings related to participants profiles, their perceptions and behavior about community life, and the effects of projects and collaborations based on mutual exchange. This work includes an analysis of the scope of the initiative based on The Social Design Pathways Tool.

Keywords | social innovation, social design, participation, experience-based learning, community building, urban gardening. 


\section{Resumen}

El presente documento pretende contribuir al conocimiento y la investigación sobre cómo las universidades pueden utilizar sus recursos para construir puentes a través del diseño y la innovación social con sus comunidades circundantes. Se basa en el caso del HUB de Diseño Social de CENTRO de diseño, cine y televisión, de la Ciudad de México y su proyecto de jardín urbano, CULTIVA, una iniciativa conjunta basada en la colaboración transversal y la creación de valor compartido. El documento informa sobre el desarrollo de CULTIVA como un espacio de aprendizaje y la interacción social en un barrio con una fuerte disminución en el espacio público y vida de la comunidad y comparte hallazgos relacionados a los perfiles de los participantes, sus percepciones y comportamiento de vida de la comunidad y los efectos de proyectos y colaboración basada en el mutuo intercambio. El trabajo incluye un análisis del alcance de la iniciativa con base en la Matriz de las Rutas del Diseño Social.

Palabras clave | innovación social, diseño social, participación, aprendizaje basado en experiencia, construcción de comunidad, huertos urbanos. 


\section{Introduction}

CENTRO is a young and dynamic private higher education institution founded in Mexico City in 2004, specialized in the creative professionalization in the fields of design, communication, film, architecture and new media. Since its foundation, CENTRO has had an interest in the connection between higher education and social impact. Chairs, faculty members, and students have worked together on projects that prioritize social agendas, and its graduates have become committed professionals and citizens, aware of their agency to create positive social change. As a result, undergraduate and graduate students have designed over 100 projects for solving social challenges related to health, education, fair trade, social inclusion, housing, aging, or sustainability, among other topics.

In 2015 CENTRO was relocated to a new campus designed to accommodate its growing student body and according to the standards of LEED Platinum certification. However, the economic and social complexity of the new neighborhood led to challenges regarding the role of the university in the community. In this new context, CENTRO formalized the creation of the Social Design HUB as transversal coordination to all its majors, postgraduate and master's degrees. Under an experience-based learning approach, the HUB seeks to promote co-creation and collaborative problem solving (PISA, 2015, NESTA, 2016) for the designing of projects with social value that strengthen the community from different perspectives (urban, economic, social, cultural, etc.) while developing skills in students that improve their potential and agency regardless their chosen career paths.

One of the most emblematic projects of the Social Design HUB has been CULTIVA, an urban farming project that aims to build an educational and social space to foster capacity development (in students and neighbors), community empowerment and, consequently, the gradual impact on the generation of small ecosystems and microeconomies for the area. 


\section{The HUB and the Community}

Universities could be providing much more brainpower to solve the problems of the communities they live in. (...) Students' wish to be better prepared for work and life. Students are well aware that not much real work involves studying solo to absorb knowledge (...). Understandably they want a more real-world experience of problem solving in teams. (NESTA, 10 Predictions for 2016: Challenge-driven universities to solve global problems)

The Social Design HUB focuses much of its time and efforts in building relationships, collaborations and mutual exchanges with the surrounding community of the campus at the América neighborhood. Along with areas 16 de Septiembre and Daniel Garza, America is located in the west of the city, forming part of a complex enclave at the Miguel Hidalgo municipality that is flanked by two important avenues and a high-speed highway. Over the past two decades, this enclave has suffered the negative effects of urban renewals and the sprawl of the city to the west, letting to isolation, poor air quality, mobility problems, insecurity and the fragmentation of its social fabric. The area has a heterogeneous social composition with mixed uses, combining highly deteriorated dwellings with ground-floor retail activities (groceries, food stalls, pharmacies, locksmiths, liquor stores, etc.). The inhabitants are mainly adults and young adults (OVIE, 2017), who do not usually participate in public or community activities.

The community has a strong deficiency of recreational spaces and public life. The very few public areas are inadequate, underused and poorly designed. A good example is the unfriendly metal fence that barriers the entrance of the Municipality's library and cultural center Faro del Saber on Sur 128 Street, at the heart of America. An underused and neglected urban space that doesn't provide shadow or a place to sit, despite having a privileged location in front of the market and being the most significant semi-open public space in the community. Other examples are two poorly designed and installed recreational areas located in the surroundings of Sur 128 on approximately $30 \mathrm{~m} 2$ and $40 \mathrm{~m} 2$ of asphalt paving. 


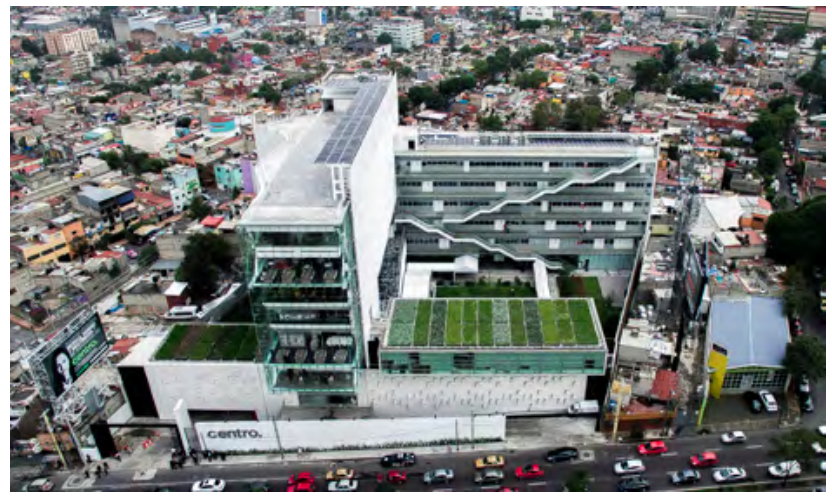

Fig 1. CENTRO Aerial view and surroundings, 2016. (Photo: José Jasso)

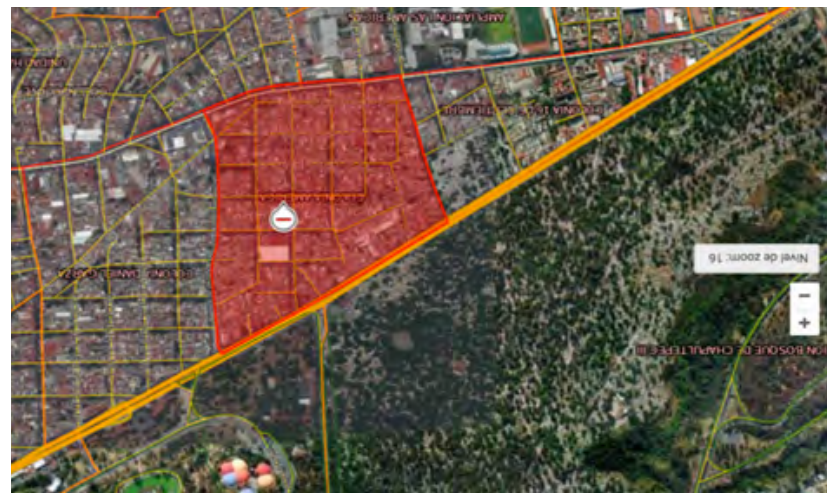

Fig 2. Enclave map. America neighbourhood in red. Google maps.

Concerning mobility, the urban interventions of the past decade to improve circulation and safety have had a negative impact in the public life. The removal of traffic lights on Constituyentes Avenue to make it a high-speed road and the construction of underpasses for cars, have isolated the community from the Chapultepec Park (the biggest one in the city) and the historical cemetery, contributing to the decline in public space and community life. The disappearance of crosswalks and the installation of pedestrian bridges, considered to be crime hotspots and only accessible through narrow and neglected sidewalks, have posed a barrier to these assets for the community.

In 2016 a collaboration of the HUB with the Postgraduate in Futures Design (Montes de Oca, 2016), organized a community workshop under the name Journey to the Future of America, designed to explore neighbors' ideas about community spaces and its future. Participants agreed that its main public space was the market, located on 128 street, which not only lacks green or recreational areas but has serious problems related to infrastructure erosion and lack of maintenance. They also remarked the weak presence of the Faro del Saber, the wastage of public space at the entrance and its rather unwelcoming gate. The lack of community spaces has let neighbors Bárbara and Pedro (living on 130 Street) to rent their garage space for gatherings and social events. 
A more recent collaboration with the postgraduate under the name of Time Capsule (December 2017) included a mix of neighbors, designers, and filmmakers. Through a set of cards and a speculative design exercise, participants were invited to collectively imagine the neighborhood 20 years from now, using as a starting point the bad news related to crime and insecurity in the area, as well as accurate information on community assets and demographics. The outcome was the design of front pages of newspapers or magazines featuring possible future realities. One of the deliverables hypothesized about the wealthy persons from across Constituyentes (on the side of the Chapultepec Park) living over 100 years, better known as "centennials," thanks to the oxygen they would take from the America enclave.

The overall experiences with workshops and the interaction with community members suggest, not only a lack of public gathering spaces, but also low quality of infrastructure, discontent with the policy-making, inclusion of pedestrians (elderly populations, children, not to mention bike users), the poor role of authorities, and the high criminality in the area. All these, have contributed to destroying the social fabric while spreading a pervasive culture of fear and distrust.

\section{Conceptual framework}

The concept social innovation encompasses a wide range of approaches and its definition varies according to authors and organizations. The Stanford Social Innovation Review defines it as "a novel solution to a social problem that is more effective, efficient, sustainable, or just than existing solutions and for which the value created accrues primarily to society as a whole rather than private individuals" (Phills et al. 2008). Likewise, Ezio Manzini (2015) considers that social innovation occurs when people, knowledge, and material resources come into contact in a new way, creating new and unprecedented meanings and opportunities. While other definitions share the underlying principle of social added value, they also make explicit reference to the empowering of specific groups and the transformation of social relations or collaborations to meet social needs (Murray et al. 2010; TEPSIE, 2014). 
As there is no single definition, there is no single outcome. Therefore, social innovation can range from production process, technology, principles, ideas, part of a legislation, social movement, intervention, or a combination (Phills et al.); new products, services and models (Murray et. al); to social entrepreneurship and the activity of social enterprises, the reconfiguration of social relations and power structures, and new models of local economic development, societal transformation and system change, among others (TEPSIE).

Although social innovation is not attached to a specific field, it is triggered by the search for efficient solutions to social needs that seek lasting social change. Thus, much of the social and environmental initiatives of the last decades are social innovation processes that go beyond traditional boundaries and based on crosscutting collaboration. It is not a coincidence that much of the most creative action takes place in the sectorial boundaries of very diverse fields (Murray et. al).

In this scenario, the global city scene of the last decade has shown a growing interest in providing solutions to alleviate some problems associated with urban expansion. Alternatives have emerged in a multiplicity of green projects managed either by public or private institutions, cooperatives, neighborhood groups, collectives, schools, or any organization with economic, environmental or social purposes.

This trend has gradually demonstrated a myriad of benefits. On the one hand, it is shifting the paradigm that only farms and farmers should be in charge of food production. On the other, a growing number of studies are suggesting that green spaces can generate benefits in terms of better mental and physical health, improved social capital, crime prevention, reduction of urban heat, or better air quality, among others (WHO, 2016).

For author John Thackara (2015) the great diversity of green projects is primarily driven by necessity, and characterized by resilience, self-organization, and solidarity. He cites cases of urban agriculture and self-sufficiency production, which have historically gained strength in times of crisis. For example, Cuba where the fall of the USSR led to the interruption of food 
flow, triggering a citizen response for local food production and its subsequent regulation. It is revealing that $12 \%$ of the urban area of Havana is dedicated to urban agriculture.

In this regard, another interesting example comes from Yue-man Yeung (1983). During 1980 a successful community garden program took place in the city of Manila at a 1.5-hectare located between two squatter communities at Matalahib neighborhood. The project thrived with the contribution of different stakeholders (local authorities, university, experts and a community group) and for over a year, the garden produced up to 80 percent of the needs of 400 families and was visited by locals and externals. The experience suggested that urban gardening could serve as a tool for urban revitalization and have a positive effect in the reduction of exclusion, gang fights, and malnutrition. Unfortunately, the project ended when the government sold the occupied land to developers.

A more recent case was seen in Spain during the last decade, with the exponential growth in the number of urban gardens. According to Gregorio Ballesteros (2014), these have increased from 2,492 in 2006 to 15,243 in 2014, a phenomenon he attributes to both a global trend and the economic crisis.

Either as the result of economic crisis, increasing awareness or global trend, it is very significant that 25 - 30 percent of world's urban population is growing food locally (Urban Agriculture in the Developing World, 2013). Worldwide, more and more cities are moving towards greener agendas with the adoption of diverse models and policies; just to mention a few: in 2015 mayors form more than 100 cities of the world signed the Milan Urban Food Policy Pact, to coordinate efforts around food systems and urban agriculture. Vancouver plans to become the greenest city in the world by 2020 through a plan that includes the production and consumption of local foods. Copenhagen, the European Green Capital of 2014, requires new buildings to include a green roof; Paris recently passed a law to invite citizens to grow food free of toxic pesticides in any place or public space (sidewalks, parks, walls, facades, and roofs); San Francisco is promoting the agricultural and commercial activity in residential, commercial or industrial areas; Medellin has a Public Policy on Food 
Security, Food Sovereignty, and Nutrition, which includes agricultural production in the city; Cape Town has an Urban agriculture policy which promotes food security and aims to build social capital by supporting female farmers.

In the local context, Mexico City's government has made numerous efforts to promote the creation of green roofs, orchards, and urban gardens. In 2016, the Congress passed the Law of urban gardens to encourage food production in the city. According to an urban and periurban agriculture report (FAO, 2014), Mexico City is one of the ten Latin American cities that stand out for their urban agriculture. Further steps are being taken with the announcement of "Espiga," the most extensive urban garden in Latin America, and with the plans to install 11 orchards in seven housing units in the city (FAO, 2017).

Urban gardens not only provide benefits as regards of food production but also can contribute in the sense of wellbeing and in building stronger communities. A recent study (Catell et al., 2017) noted that sociability and face-to-face interaction in spaces could give relief from daily routines, sense of community, opportunities for bonding ties or making bridges, and influence tolerance. Likewise, other studies have pointed out that green spaces are linked to the creation and strengthening of social networks, the exchange of information, and the increase in social connectivity and collective pride that can inspire community for other improvements (Wolf \& Rozance, 2013).

In this context, Blewitt (2015) points out that poor quality built environments can affect the physical and mental health and trigger anxious and aggressive behaviors in contexts commonly associated with crime, disorder, noise, traffic, and pollution, while relaxing and peaceful urban green areas can restore the sense of wellbeing of the inhabitants. According to Cattel et al. (2008), the quality of public space is commonly perceived as a measure of the quality of urban life.

Regarding security issues, a study of the University of Pennsylvania (2012) suggested that neighbors living near greened vacant lots felt safer, while incidents of police-reported 
crimes seemed to decrease (Garvin et al., 2012). Previously, a nine-year period research (2011) observed the impact of the Philadelphia LandCare Program, concluding that the greening of vacant lots could result in the decrease of armed robbery and vandalism and the improvement of the quality of life among residents.

Whether from an organization, movement, educational institution, design agency or artist, there is a myriad of social innovation projects happening around the globe focused on urban agriculture and green infrastructure. Universities are no exception on these issues and have given rise to projects such as COLTIVANDO, a collaborative, productive garden developed by designers and community as part of an educational and research initiative of the DESIS Lab Polytechnic of Milan; Grow Dat Youth Farm in New Orleans, a collaborative farm incubated by Tulane University and the Community Design Center of the School of Architecture, which seeks to motivate young people from different contexts to create environmental change through a more just and sustainable food system; or the Dronsife Center of Drexel University in Philadelphia, a neighborhood resource which gathers knowledge and expertise of local partners and hosts activities for Drexel communities and neighbors, including a community vegetable garden.

\section{CULTIVA: a bridge for collaboration}

The HUB shares the theoretical and methodological approaches of Ezio Manzini (2015) regarding design for social innovation, nevertheless it should be noted the existence of a conceptual distance in terms of his understanding of social design, considered as a welfare practice, linked to helping marginalized populations or users that can't afford design services and, therefore, providers must do it motivated by ethical principles and under charitable schemes.

For Ezio Manzini design for social innovation "entails a sociotechnical transformation driven by and oriented towards social change" and occurs through a social conversation or "co-design" between different actors interested in achieving the same result under an 
innovative approach. According to him, design experts should be able to guide and feed the conversation of the co-design process, through a dialogic capability and supported by their creativity and culture, keeping in mind that they are making things happen as part of a design process which they support but cannot control (2015). In this line of thought, Manzini states that more and more people are rediscovering the importance of collaboration and that community gardens are an excellent example of places where, in addition to creating more and better green areas, it's possible to make friends and build community.

That said, the CULTIVA urban garden initiative is an entirely new project developed under a co-designing approach and oriented towards social change. An initiative primarily aimed to promote networking, exchange of information, knowledge, and ideas within the extended community of CENTRO (mainly neighbors, students, and university staff). CULTIVA is the result of combining people, ideas and practical design tools and creativity from the design context, to align different efforts. Collaborations range from the master gardener of CENTRO, to undergraduate students of Industrial Design, Fashion Design, Marketing, Visual Communication, Digital Media, Interior Design and Film, who have worked together in several aspects of the initiative (naming, visual identity, DIY orchard modular system, workshop contents, booklets, posters, social networking and even short videos for its promotion), as well as graduates students from the Master in Design Studies.

Objectives:

- Promote experience based learning and collaboration.

- Reach and engage the community through urban gardening workshops.

- Promote the creation of orchards and green areas, which could bring social benefits and support local micro economies.

- Build links, share and exchange knowledge to encourage the development of a more integrated and supportive community.

- Combat disinformation regarding community issues. 


\section{Project Design}

CENTRO's campus is a Platinum LEED certified building with specific attributes that must be kept according to its original design. Despite the presence of beautiful roof gardens and green areas, the installation of an urban garden posed a challenge for the HUB, due to the building's design and the lack of available spaces. In 2016, the research for the bachelor's degree thesis in Industrial Design of Cristina Espinosa (Verde Raíz, 2018), proposed a DIY modular orchard system for home use that could help deal with the lack of green areas in the community, the limitations of space in homes, and the high costs associated with urban gardening infrastructure. The system was adopted by the HUB as a first step in the creation of an orchard garden. Espinosa's idea came while coursing the seventh semester, where she was strongly inspired by the Social Design mandatory course, where students reflect on the potential effect of their practice and develop projects for and with the surrounding community under a collaborative approach.

Her research was supported by faculty, students, neighbors and the master gardener of CENTRO, Vicencio García, who not only contributed with knowledge and feedback on different topics (material strength, design, functionality, types of crops) but in the testing of the prototypes in different spaces and conditions over time.

\section{DIY Model}
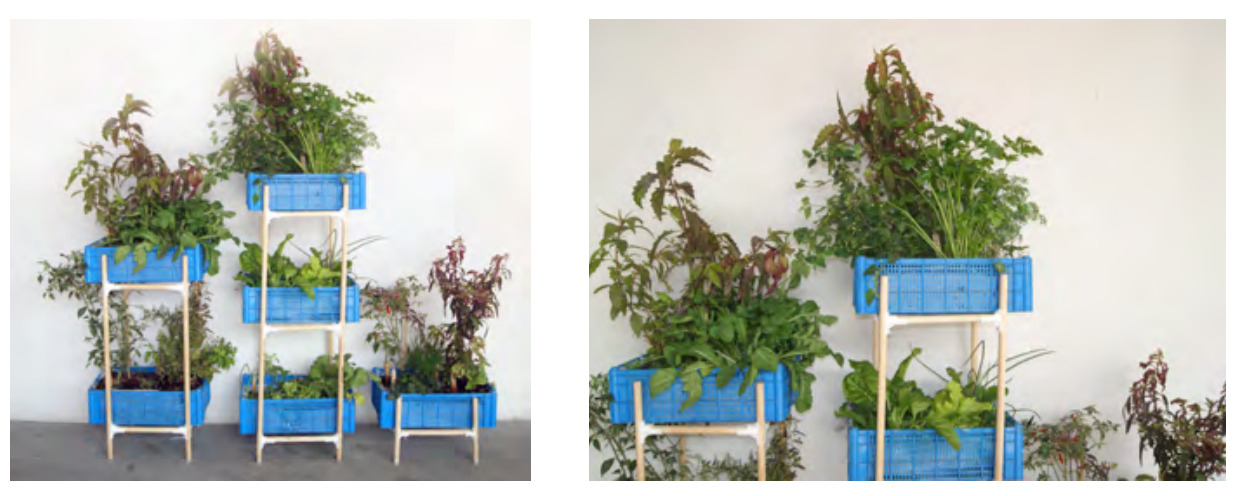

Figs 3 \& 4. DIY Module with connector produced through a plastic injection moulding process. Social Design HUB, 2017 

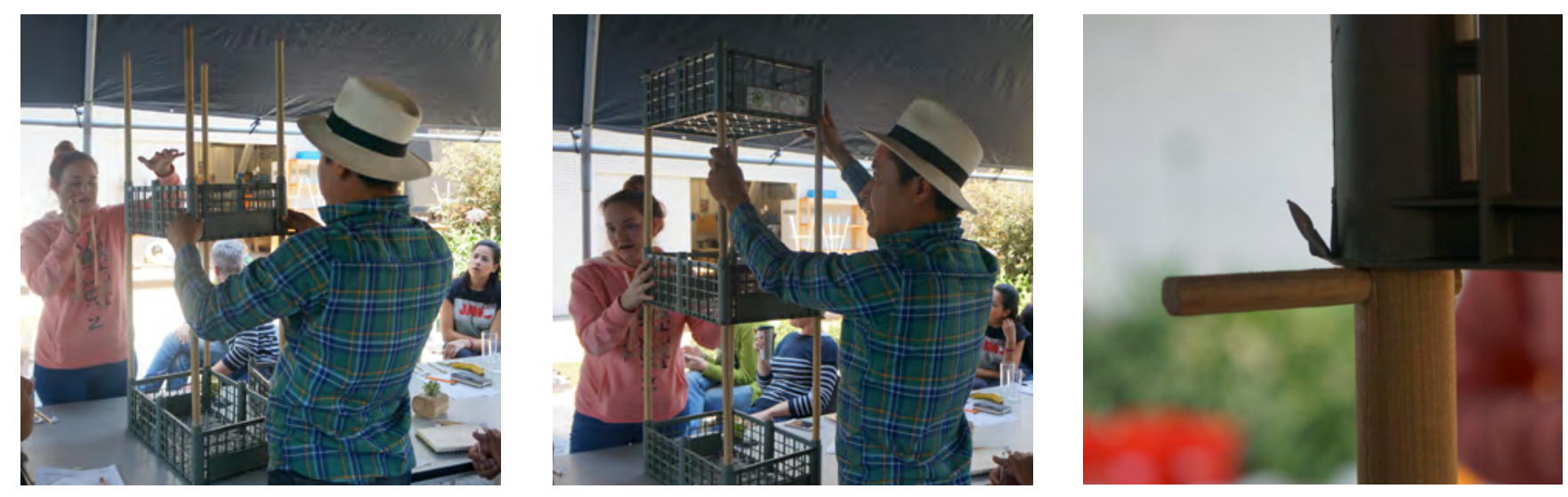

Figs. 5, 6 \& 7. CULTIVA demonstration of create assembly and D.I.Y system Social Design HUB, 2017.

The DIY modular orchard system is based on $45 \times 30 \mathrm{~cm}$ polypropylene plastic high-density crates with $15-30 \mathrm{~cm}$ depth (usually reused and bought at very low prices at local markets) depending on the type of crop that will be planted. With the addition of plastic and tape, the crates can be sealed inside to avoid the leakage of water and substrates. These low-cost crates are highly functional due to their strength and lightweight and because they do not require significant modifications for assembly. (See figures 3, 4, 5, 6, 7).

To prop up the crates in different heights, 7/8"wood sticks (broomsticks) are assembled on its corner-holes. Wooden dowels are also inserted through the sticks, attaching the crates at the desired height (leaving space for ventilation, irrigation, care, and growth). Maximum dimensions are $30 \times 40 \times 120 \mathrm{~cm}$. The overall cost can range from $\$ 50$ to $\$ 85$ pesos for crates and sticks, and around $\$ 120$ pesos including shade net, plastic, substrate, and seeds.

While this is its most straightforward mode and it has proven to work, Espinosa developed a connector plastic piece aimed to give more stability to the structure, provide support to the base and connect the sticks. First prototypes were produced through a plastic injection molding process and are currently being tested at CULTIVA and a neighbor's orchard. While this solution might result in higher costs, 3D printing could be an alternative to giving the DIY modules more strength and stability in the long term. 


\section{Workshop Delivery: From Product Design to Community Engagement}

After initial tests and adjustments, the prototype for the DIY modular orchard system became the foundation of the pilot project CULTIVA. This initiative of the HUB aimed to offer the community basic knowledge and tools for starting their gardens. To that end, the master gardener along with a group of social service students (Mexico requires all undergraduates to complete 480 hours of social work in order to earn their degree) planned a workshop under a theoretical and practical approach, which required the gathering of samples in the field, and the design of materials such as the pest and disease control instruction booklet for participants (see Fig. 10).

The first pilots of CULTIVA workshops were delivered to neighbors and CENTRO's students and staff in Fall 2016 by the master gardener with the support of social service students. Recovery rate was $\$ 100$ pesos in exchange for the workshop and materials, which included a simple modular orchard kit (plastic crate, substrates, seeds, wooden sticks, labels). Participants were organized into two groups to work for three fortnightly Saturdays on four-hour sessions for a total of 16-hours. With the workshops, the HUB established that materials should be purchased at the local market to support neighborhood economies.

\section{CULTIVA workshop syllabus}

Day 1 Self-introduction of participants to the group Types of vegetables, orchard organization, places and plots, distribution, types of seeds, sowing, planning, growing beds, types of soil.

Practice: creation of personal mini garden.

Day 2 Germination, types of germination, planting trays, planting season Practice: preparation of seedlings and germinating trays, preparation of seeds

Day 3 Transplants, rooting, composting, seedlings and care. Practice: Transplant a variety of vegetables, medicinal and aromatic. Rooting: stevia, steam, mint, etc.

Day 4 Botanical extracts, natural cure for pests and diseases Practice: identification of pests and diseases on plants and vegetables, preparation of botanical extracts 

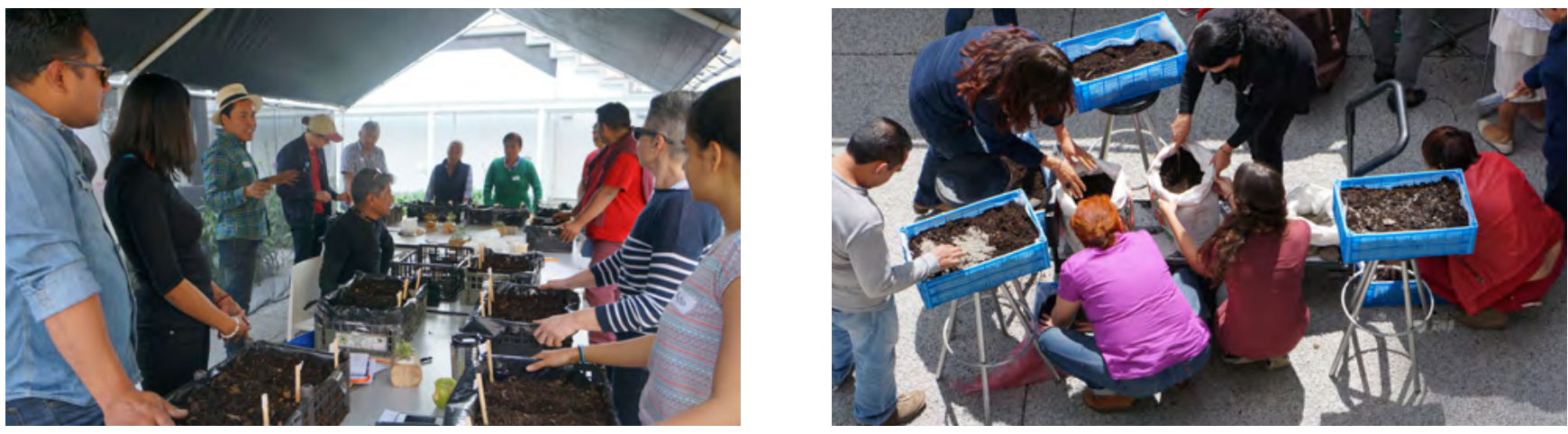

Figs 8 \& 9. Configuring crates and sowing seeds. Social Design HUB, 2016.
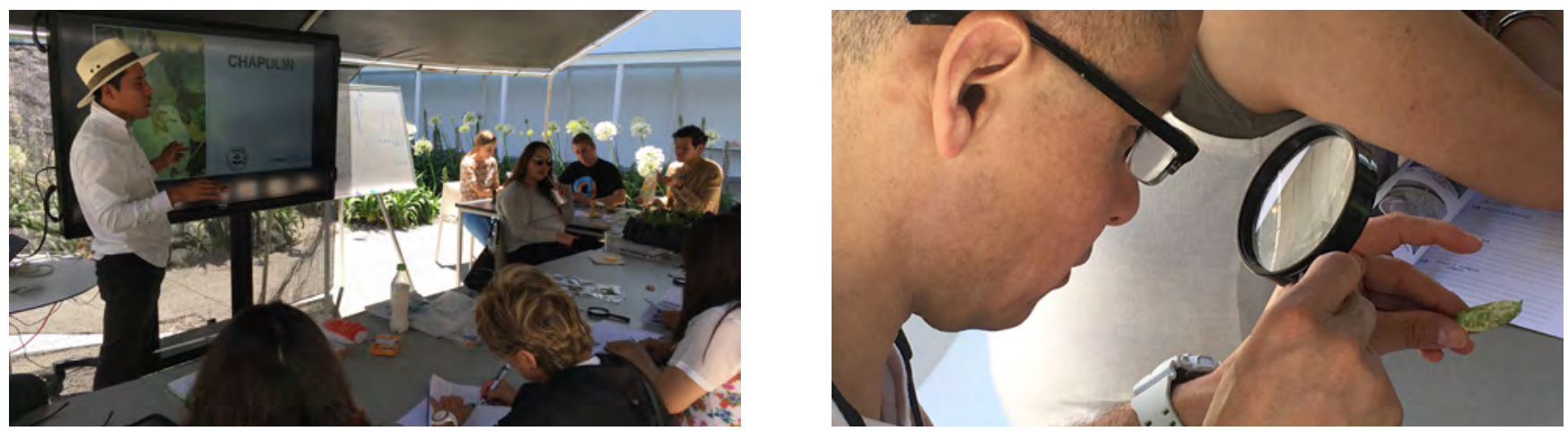

Figs 10 \& 11. CULTIVA workshop. Plagues and diseases activities. Social Design HUB, 2017.
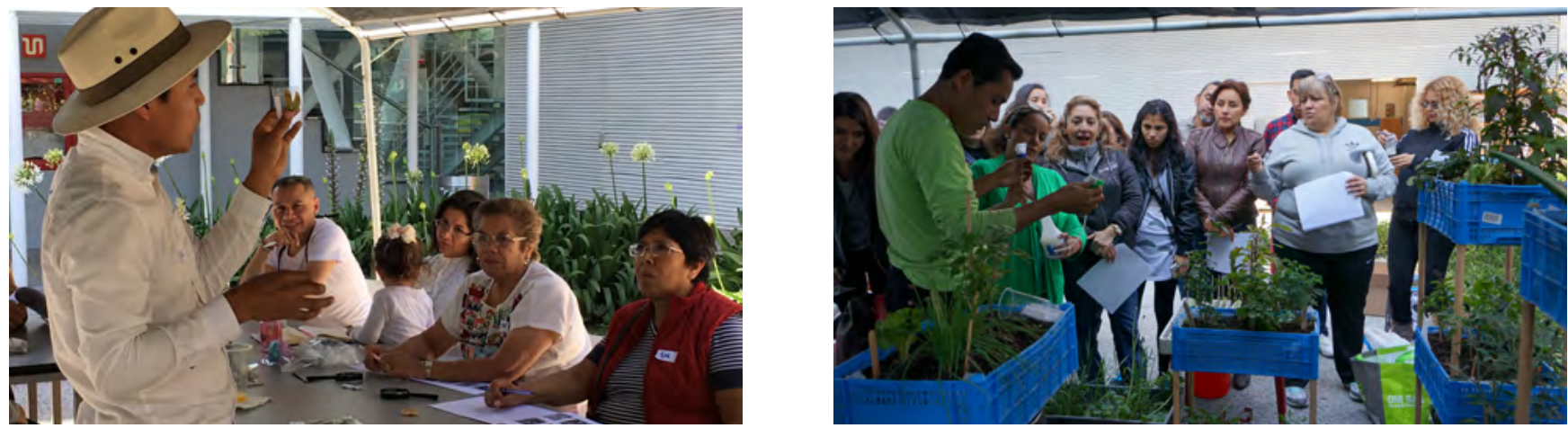

Figs 12 \& 13. Workshop sessions. Social Design HUB, 2016 y 2017. 
Throughout the workshop, participants have a theoretical-practical experience that allows them to learn the techniques and replicate them elsewhere while observing the process of growth in their DIY orchards. Each session is open to constant feedback and questions and includes a 20-30 min coffee break, to mingle and network.

At the end of the 16-hour, participants receive a certificate of achievement and celebrate a gathering (with some fresh herbs harvested from the gardens) that often brings together different groups of CULTIVA.

\section{Results}

The pilot was launched in 2016. The two groups had an attendance of 15 and 17 respectively. During the closure and final gathering (that brought together both groups), qualitative assessment surveys with open-ended questions were applied. The aim was to get feedback, contact details, and other demographic information while gathering opinions related to workshop expectations, previous knowledge on the topic, what they liked most about the experience, as well as any change of perception (good or bad) about CENTRO. Findings were obtained from 24 responses ( 22 from neighbors and two members of CENTRO) with a significant predominance of the female population (87\%). It is important to mention that 25 percent of participants were missing in this final activity; therefore results might vary slightly. Participants profile:

\begin{tabular}{llll} 
Age & \multicolumn{3}{l}{ Gender } \\
\hline Under 15 years & 3 & Female & 21 \\
\hline $15-24$ & 4 & Male & 3 \\
\hline $25-34$ & 0 & & \\
\hline $35-44$ & 5 & & \\
\hline $45-54$ & 7 & & \\
\hline $55-64$ & 2 & \\
\hline $65-75$ & 3 & \\
\hline
\end{tabular}




\section{Most liked}

Representative answers to the question: What did you like most about participating in the workshop?

We had the opportunity to put in practice the planting; all queries were solved, and all the topics were interesting. Lizbeth Castellanos, 43 years old (CULTIVA Workshop Survey, 2016). Sharing with the neighbors and the instructors, in addition to learning. María de los Ángeles Cervantes, 75 years old (CULTIVA Workshop Survey, 2016).

Of the 24 responses, 15 agreed that what they liked most about having being part of the workshop was practical learning, while seven said it was the sharing and/or meeting of new neighbors. In five cases the answers were combined, referring to learning and/or sharing with neighbors as a secondary topic.

Perception about CENTRO:

Representative answers to the question: Did attending this workshop change in any way (positive or negative) your perception of CENTRO?

Yes, CENTRO is interested in our community, in its growth and improvement. Ana María Montes de Oca, 61 years old. (CULTIVA Workshop Survey, 2016.)

Yes, I like to come to CENTRO more and more. Thank you CENTRO! Irma Patricia Hutrión, 55 years old. (CULTIVA Workshop Survey, 2016).

All of the respondents (24) indicated that their perception of the university changed for good, mentioning topics like the friendliness and disposition of students and staff, or the debunking of false claims regarding the university. For example, when CENTRO opened its campus, people sparked rumors on the high water consumption of the building, causing discomfort due to the water scarcity in the community. In response, CULTIVA workshops included a guided visit to the building, its green roofs and an explanation of the water 
recovery and recycling systems. Thus, participants were able to verify that the building mostly consumed collected rainwater and had nothing to do with the water scarcity problem of the neighborhood.

It should be noted that 13 respondents (54\%) affirmed they have not had previous contact with CENTRO.

Perception about the community and new contacts

Representative responses to the question: Did attending this workshop allow you to meet new neighbors and/or change your perception of the community?

Yes, I met valuable people, and I learned that our community is not only what we see and judge. Meet and know our neighbors is good. Elizabeth Torres, 44 years old (CULTIVA Workshop Survey, 2016).

Yes, the neighborhood tends to have a bad reputation, with this and other projects you are inviting the community to show that there are people who are not as the other people think. Fernanda Segura, 23 years old (CULTIVA Workshop Survey, 2016).

Hundred percent of the participants in the survey responded that they met new neighbors. Additionally, some mentioned that these activities favored the change of perception about the community and its inhabitants.

On this regard, it should be noted that informal conversations, Facebook posts on CENTRO's networks and interviews with students and experts at the university about CULTIVA and other projects of the HUB, suggest a change of perception for good in both directions. When the campus first moved to the America neighborhood, the rumors of insecurity and the unfamiliarity of the place, contributed to show prejudice against the community. Likewise, the building of a private university led to a feeling of rejection in some neighbors, who mistakenly believed the university would take its water supply and bring along other problems. 
During 2017, the CULTIVA workshops divided the survey between an entry and an exit questionnaire. This made it possible to gather contact information in the first part, and anonymous feedback on their experience in the second. Both parts contained open-ended questions, the first one, regarding expectations and how participants learned about the project, while the exit one, asked about changes in perception about CENTRO and the community (for good or bad), if the workshop helped in getting to know new neighbors, or if it met their initial expectations. It is worth mentioning that the average rate of missing participants per group was 15 percent, which might result in a bias. The respondents (57) revealed very similar results to the previous findings: the wide age range of participants (7-76 years); the large proportion of female population; the level of satisfaction with the practical component of the workshop; the meeting of new neighbors (reported affirmative in all responses except in the few cases of external participants).

Additionally, the survey incorporated the open-ended question: Do you usually participate in community activities? Eighty to ninety percent of respondents in four editions of the workshop during 2017 reported they did not. Special attention should be given to the fact that the very few neighbors participating in other community activities are persons attending Senior Activity Centers or the Cultural Community Center Faro del Saber.

By the end of 2017, CULTIVA workshops had reached seven editions and 98 participants between ages 7 and 76 years old. The group sizes varied from 7 to 25 persons including students, university staff, and neighbors mostly, who were invited through word of mouth referrals, street outreach, posters, Whatsapp and social media (HUB, CULTIVA and more recently CENTRO).

CULTIVA has had impacts that are difficult to measure and quantify, but that are very important for the goals of the Social Design HUB. For example, about 25 to 30 percent of the participants continue collaborating in activities and workshops, and many of them have become close friends among them. Some other participants are business owners in the area (ice cream shop, hardware store, street vendors, etc.) that have strengthened their relation- 
ships with the university and other members of the community, helping them grow their customer base. Another example is the case of neighbor Guadalupe Mejia, a close collaborator for the design and testing of the DIY modular prototype, who has taken part of many workshops and activities and has become a provider for small and medium-sized catering services at the university. Guadalupe has also delivered a couple of workshops for students and neighbors related to food and tradition as part of the Day of the Death activities.

\section{Improvements}

The CULTIVA project was officially launched in Spring 2017 as an experienced-based learning permanent initiative to foster exchanges and community cohesion. Over the year, and with the collaborative efforts of outside experts, students, and neighbors, CULTIVA was able to expand in different ways:

Continuing education: due to the demand of external people the workshop was incorporated into the continuing education program, offering a few spaces for outsiders at its real cost (recovery fee is a privilege that must be kept for community members, students and staff, all earnings from other external fees are used to sustain the program).

- Increase in recovery fee to $\$ 350$ pesos (\$18 USD): after the pilot, it became clear that people were willing to make a higher and more realistic exchange for the workshop. This is important, since the aim of the HUB is to avoid charity and encourage mutual exchange.

- Logo and identity design: two undergraduate students from Marketing and Visual Communication undergraduate degrees, respectively, made the proposal for the logo to the group and refined it until reaching the final identity. This was applied to printed materials, tags, social networks, etc. 
- Production of succulent plants: the yearly celebration for teachers included a present consistent in a small baby succulent taken from the green roofs and planted on biodegradable pots with the tag of CULTIVA and care instructions. Gradually, other areas of the university started asking for plants, and soon the productive capacity was exceeded.

- Expansion to a new site: in 2018 with the help of social service students from Fashion and Textile Design, Interior Design and Industrial Design, CULTIVA will expand towards an underused area of the university to have a permanent site for production and teaching.

- Workshops and activities as exchange: CULTIVA delivers free one-day practical sessions where volunteers receive knowledge and plants in exchange for help in transplanting plants into small pots.

- Learning space for regular classes: CULTIVA launched collaborations with faculty members who bring their class to the orchard area in order to learn and experience the project, while reflecting on innovations that could add value to it.

- Toolkit for community gardeners: visual and written tool for printed and electronic distribution that will allow sharing the contents and methods of CULTIVA workshop under a free license. Contents and design are being developed in collaboration with social service students.

- HUB day: every Wednesday the HUB features a special open activity related to a different workshop. Therefore, once a month CULTIVA followers can learn about topics such as medicinal plants, fruit trees, seed banks or have an open conversation on sustainable issues. Faculty, external experts, students, and neighbors can be invited to guide the session. 


\section{Design Routes for Social Innovation}

The Pathways in Social Design Matrix is a tool proposed in 2013 by a group of experts at the Winterhouse Symposium for Education and Social Change. It seeks to map the terrain, stakeholders' involved and potential impacts of social design projects. As its description states, it can be useful to help guide an initiative, reveal the participants, partners, resources, and required skills for action, scales of engagement, and possible outcomes for a given challenge.

The matrix allows the analyzing of projects in light of their real or potential impact. In the following section, the method is applied to CULTIVA, through the review of past and present stages, and by projecting some future and desirable scenarios in the long term.

RANGE OF EXPERTISE brought to bear on the project

\begin{tabular}{|c|c|c|c|}
\hline & & & \\
\hline $\begin{array}{r}\text { Cultural } \\
\text { (transformaton) } \\
\text { Changing } \\
\text { the attitudes } \\
\text { and behaviours } \\
\text { of a community } \\
\text { or organization }\end{array}$ & & & $\begin{array}{l}\text { Create partnerships and transform } \\
\text { vacant spaces in the community } \\
\text { (including the Faro square) in green } \\
\text { and productive areas for neighbors. } \\
\text { Promote urban agriculture } \\
\text { and exchange. }\end{array}$ \\
\hline $\begin{array}{r}\text { System } \\
\text { (innovation) } \\
\text { Altering an existing } \\
\text { system, or creating } \\
\text { a new one, } \\
\text { to deliver } \\
\text { a better solution }\end{array}$ & $\begin{array}{l}\text { Replace welcome gifts for new } \\
\text { students with plants from CULTIVA, } \\
\text { produced in-site with the } \\
\text { collaboration of students and } \\
\text { neighbors. }\end{array}$ & $\begin{array}{l}\text { Create a network of urban } \\
\text { gardeners on plots, balconies, } \\
\text { rooftops or any free space, } \\
\text { who are trained and oriented } \\
\text { according to their needs } \\
\text { through CULTIVA. }\end{array}$ & $\begin{array}{l}\text { Offer workshop of speculative } \\
\text { design aimed to deliver proposals } \\
\text { for public and green spaces. } \\
\text { Empower neighbors and submit } \\
\text { proposals for the participatory } \\
\text { budgeting. }\end{array}$ \\
\hline $\begin{array}{r}\text { Stand-Alone } \\
\text { (intervention) } \\
\text { The introduction } \\
\text { of a discrete } \\
\text { product } \\
\text { or service }\end{array}$ & $\begin{array}{l}\text { Design of a modular DIY orchard } \\
\text { system that can be assembled with } \\
\text { reused plastic crates and wood } \\
\text { sticks. }\end{array}$ & $\begin{array}{l}\text { Comprehensive workshop based } \\
\text { on the DIY modular system and } \\
\text { a theorical-ptractical course, } \\
\text { designed and delivered in } \\
\text { collaboration with master gardener, } \\
\text { industrial designer and social } \\
\text { service students. }\end{array}$ & \\
\hline & $\begin{array}{l}\text { Individual (designer) } \\
\text { A lone person or discipline }\end{array}$ & $\begin{array}{l}\text { Interdisciplinary (team) } \\
\text { A team made up } \\
\text { of the necessary expertise }\end{array}$ & $\begin{array}{l}\text { Cross-sector (group) } \\
\text { Requires cross sector participation } \\
\text { for ideation and execution }\end{array}$ \\
\hline
\end{tabular}




\section{Quadrant description:}

Stand-Alone / Individual:

The intervention is the prototype designed by student Cristina Espinosa as part of her bachelor degree thesis dissertation in Industrial Design. This mostly considers the technical aspects of the proposed D.I.Y. module, "consisting of three plastic crates and four wood sticks."

Stand - Alone / Interdisciplinary:

CULTIVA's main component is a comprehensive workshop based on the DIY modular system and a theoretical-practical 16-hour course that was co-designed and delivered by a variety of participants, who contributed with their experience, knowledge, and skills.

System / Individual:

The HUB proposed to give plants as a gift from the university slowly replacing welcome gifts by grown in-site plants from CULTIVA. This is possible through the collaboration of social service students, externals, and neighbors who, in exchange, receive a brief workshop on transplantation and plants.

System / Interdisciplinary:

In the medium-term, it would be desirable to consolidate a network of urban farmers cultivating on plots, balconies, rooftops or any kind of free space. Farmers would be trained by CULTIVA and advised for solutions according to their specific needs. The network would have a positive social impact through the strengthening of community relations, "the creation and improvement of green areas", the production of vegetables and fruit trees, the reduction of urban heat island effect, the air quality, and the overall satisfaction and communication among neighbors.

\section{System / Cross-Sector:}

In collaboration with the postgraduate in Future Design, the HUB has been collecting information and opinions on critical issues for the community, among which, the lack of green and public spaces rank very high. The intention is to offer a series of workshops on specu- 
lative design aimed to deliver proposals for the creation of green and public spaces in the area, and invite neighbors to submit results in the participatory budgeting, which has very low participation rates.

\section{Cultural / Cross-Sector:}

In the long term, it would be desirable to adopt a collective impact approach and seek the combination of efforts of different stakeholders in the area (universities, public and private schools, private hospitals, etc.) working towards common goals (Kania and Kramer, 2011). This would include the recovery and transformation of vacant lots and other potential spaces into green and productive gardens, under a low-cost and collaborative design scheme to make it replicable. The initiative would be aligned with recently approved law on urban farming in Mexico City, and could benefit not only the production of local food and the image of the neighborhood, but the social relations, the sense of trust and engagement, and even the perception of security in some areas. 


\section{Conclusions}

This paper analyzed the creation and development of CULTIVA as a social innovation tool, designed for building bridges between CENTRO university and its surrounding community. The results have demonstrated how with very few material resources, and even lacking of a physical green space, it is possible to launch an urban gardening project that can result in a learning experience, and in a space for social interaction and knowledge exchange in a very complicated area of the city.

At the close of this paper, the CULTIVA process, including the research phase for the development of the DIY module, was 16 months old. The evidence and feedback obtained through the past seven editions confirm the relevance, interest, and viability of the initiative. There are good reasons to believe that the effort of working with the community through CULTIVA can be a mutual advantage for the university and the community.

Some benefits are: the possibility of developing solutions to real social problems (experienced-based learning, the collaboration and exchange between students and users, the gathering of information and feedback regarding community issues and its possible solutions, the building of trust among neighbours, students and staff; the promotion of community services that can solve needs for the university, and the support of local economies (most of the materials used in CULTIVA, and other workshops of the HUB are bought in the local market).

A valuable lesson of this experience is the fact of being based on student's research on community needs and how this initial idea was able to escalate into a collective project. This suggests that designers interested in social innovation should always bear in mind the complex layers of collaboration needed to be effective and, of course, seek expert and community guidance (which in a way are the only experts in their problems).

As far as the social sphere is concerned, informal evidence and information gathered through the surveys, suggest that although participants do not usually take part in neighborhood group activities (mostly because they are inexistent), they have been receptive and 
open to collaborating. This is, some persons are willing to break the apathy and the dominant patterns of behavior to be part of this initiative. In this sense, it is not unreasonable to aspire in the medium and long-term, to a gradual cultural change in the behavior of more and more people, who will gain trust and empowerment, while working together in the recovery and preservation of their community.

Finally, it must be noted that the use of Participation Map and the Pathways for Social Design are not only relevant for a better understanding of CULTIVA and its possibilities, but also for the reflection on the usefulness of these type of instruments that tend to remain underused. It is important to emphasize that CULTIVA is an open project, based on the creation of shared value, and built on crosscutting collaboration and co-design. Therefore, ideas, findings, and feedback from different people in the coming months will be crucial to define the achievements and future direction of the project. 


\section{References}

Armstrong, L., Bailey, J., Julier, G. \& Kimbell, L. (2014). Social Design Futures. Arts and Humanities Research Council. United Kingdom: University of Brighton. Victoria \& Albert Museum. Retrieved November 30, 2017 from https://mappingsocialdesign.files. wordpress.com/2014/10/social-design-report.pdf

Ballesteros García, G. (2014): Espectacular crecimiento de los huertos urbanos. Revista El Ecologista, $\mathrm{n}^{\circ} 81$. Ecologistas en Acción. Madrid. Retrieved December 12, 2017 from https://www.ecologistasenaccion.org/ article28265.html

Blewitt, J. (2015). Urban Sustainability: Key Issues. London: Routledge

Branas, C., Cheney, R., MacDonald, M., Tam, W., Jackson, D. \& Have, R. (2011). A Difference in Differences. Analysis of Health, Safety and Greening Vacant Urban Space. American Journal of Epidemiology, 174 (11). Retrieved January 3, 2018 from https://academic.oup. com/aje/article/174/11/1296/111352?keytype=ref\&ijkey=9pNc5FdhqLOAvbU

Cattell, V., Dines, N., Gesler, W. \& Curtis, S. (2008). Mingling, observing, and lingering: Everyday public spaces and their implications for well-being and social relations. Original Research Article Health \& Place, 14, 544-561. Retrieved December 12, 2017 from http:// illinois-online.org/krassa/ps450/Readings/Cattell\%20 Mingling \%20in\%20public\%20spaces \%20and\%20 well\%20being \%20(smaller).pdf

COLTIVANDO. L'Orto Convivale. DESIS Lab. Politécnico de Milano. Retrieved November 30, 2017 from www.coltivando.polimi.it/il-progetto/che-cose/

Cooke, L. (2016). "Paris allows anyone to plant an urban garden". Inhabitat. Retrieved December 3, 2018 from http://inhabitat.com/paris-allows-anyone-to-plant-anurban-garden-anywhere/
Cubbin, C., Egerter, S., Braveman, P. \& Pedregon, V. (2008). Where We Live Matters for Our Health: Neighborhoods and Health. Issue Brief 3. The Robert Wood Johnson Foundation, Commission to Build a Healthier America. Retrieved January 2, 2018 from http://www.commissiononhealth.org/PDF/e6244e9ef630-4285-9ad7- 16016dd7e493/Issue \%20Brief\%20 $2 \% 20$ Sept $\% 2008 \% 20-\% 2$ Housing $\% 20$ and $\% 20$ Health.pdf

Davis, M., Hawley, P., McMullan, B. \& Spilka, G. (1997). Design as a catalyst for learning. Alexandira. Association for Supervision in Curriculum Development. Retrieved December 10, 2018 from https://archive.org/details/designascatalyst00davi

DORNSIFE CENTER for Neighborhood Partherships. Drexel University. Retrieved Novermber 30, 2017 from http://drexel.edu/dornsifecenter/

Espinosa, C. (2018). Ver(de)Raíz. Tesis de licenciatura en Diseño Industrial. CENTRO. Tesis en prensa.

FAO. " 10 ciudades latinoamericanas que se destacan por la agricultura urbana". Agronoticias América Latina y el Caribe, 2010. Retrieved January 3, 2018 from http://www.fao.org/agronoticias/territoriosinteligentes/noticias/detalle/es/c/225093/

Garvin, E., Cannuscio, C. \& Branas, C. (2012). "Greening vacant lots to reduce violent crime: $A$ randomized controlled trial". Injury Prevention 19(3): 198-203. Retrieved January 2, 2018 from http:// injuryprevention.bmj.com/content/19/3/198.full

Technical and Environment Administration, City of Copenhagen (s/f). Green Roofs Copenhagen.

Retrieved December 9, 2017 from www.klimatilpasning.dk/media/631048/green_roofs_ copenhagen.pdf

Growing Greener Cities in Latin America and the Caribbean. (2014). Food and Agriculture Organization of the United Nations. Retrieved January 4, 2018 from http://www.fao.org/3/a-i3696e.pdf 
GROW DAT YOUTH FARM, Tulane University. Tulane City Center. Retrieved November 30, 2017 from http:// growdatyouthfarm.org/

Huertos urbanos son ahora un derecho en la Ciudad de México. Food and Agriculture Organization of the United Nations. Retrieved January 4, 2018 from http://www.fao.org/mexico/noticias/detail-events/ en/c/471259/

Kopnina, H. \& Shoreman-Ouimet, E. (eds) (2015) Sustainability: Key issues. Routledge Earthscan, New York

Ley de Huertos Urbanos en la Ciudad de México. (2017). Gaceta Oficial de la Ciudad de México. Retrieved December 9, 2017 from: www. data.consejeria. cdmx.gob.mx/images/leyes/leyes/LEYDEHUERTOSURBANOSENLACIUDADDEM\%C3\%89XICO.pdf

Manzini, E., (2015). Design When Everybody Designs: An Introduction to Design for Social Innovation. Cambridge: MIT Press

Murphy, C. "Urban Gardens Increase Food Security In Times of Crisis: Habana, Cuba." Retrieved December 10, 2017 from www.flacso.uh.cu/sitio_ revista/num3/articulos/art_CMurphy13.pdf

Murray, R., Caulier-Grice, J. \& Mulgan, G. (2010). The Open Book of Social Innovation. The Young Foundation, NESTA. Retrieved October 28, 2018 from https://youngfoundation.org/wp-content/ uploads/2012/10/The-Open-Book-of-SocialInnovationg.pdf

NESTA (2011). Theory of Change Canvas. Development Impact and You Toolkit (DIY). Practical Tools to Trigger and Support Social Innovation. Retrieved November 28, 2017, from http:// www. diytoolkit.org

NESTA (2016). Challenge-driven universities to solve global problems. In 10 Predictions for 2016. Nesta News and Features. Retrieved November 28, 2017 from http://www.nesta.org.uk/2016-predictions/ challenge-driven-universities
Nikolaidou, S., Klöti, T., Tappert, S. \& Drilling,M. (2016). "Urban Gardening and Green Space Governance: Towards New Collaborative Planning Practices". Urban Planning 1, pp. 5-19. Retrieved January 4, 2018 from http:// dx.doi.org/10.17645/up.v1i1.520

Olivier, D. (2017). "Urban agriculture means food plus social cohesion". CapeTimes. Retrieved Februrary 27, 2018 from https://www.iol.co.za/capetimes/ news/urban-agriculture-means- food-plus-socialcohesion-2096857

Oficina Virtual de Información Económica, OVIE. (2017). Versión BETA. SEDECO, INEGI. Retrieved September 15, 2017 from http://ovie.sedecodf.gob.mx/ OVIEWEB/

Orsini F., Kahane R., Nono-Womdim R. \& Gianquinto G. (2013). "Urban Agriculture in the Developing World: a review". Agronomy for Sustainable Development. Retrieved December 10, 2017 from http:// publications.cirad.fr/une_notice.php?dk=571129

Phills, J., Deiglmeier, K. \& Miller, D. (2008). "Rediscovering Social Innovation". Stanford Social Innovation Review. Fall No. 6, 4. P. 34. Retrieved December 18, 2017 from https://ssir.org/articles/ entry/rediscovering_social_innovation

Rømø, D. (s/f). Green Roofs in Copenhagen.

City of Copenhagen. Retrieved December 9, 2017 from: https://stateofgreen.com/en/profiles/city-ofcopenhagen/solutions/green- roofs-in-copenhagen

Social Design Pathways. (2013). Winterhouse Symposium for Design Education and Social Change. Under Creative Commons License. Retrieved October 30, 2017 from www.socialdesignpathways.com/ download-the-matrix/

Thackara, J. (2015). How to Thrive in the Next Economy. London: Thames and Hudson. 
TEPSIE. (2014). Social Innovation theory and research. A Guide for Researchers. Deliverable no: 1.4, Brussels: European Commission - 7th Framework Programme. Retrieved November 28, 2017 from http://www.tepsie.eu/images/documents/research_ report_final_web.pdf.

Urban green spaces and health. (2016). WHO Regional Office for Europe, 2016. Retrieved January 2, 2018 from http://www.euro.who.int/_data/assets/pdf_ file/0005/321971/Urban-green-spaces-and-healthreview-evidence.pdf?ua=1

Vancouver Greenest City Action Plan 2015 - 2020.

(2015). Vancouver City. Retrieved December 10, 2017 from http://vancouver.ca/files/cov/greenest-city-2020action-plan-2015-2020.pdf

Vancouver Food Strategy: Building just and sustainable food systems. (2013). City of Vancouver. Retrieved December 10, 2017 from http://vancouver.ca/peopleprograms/vancouvers-food-strategy.aspx

Wilson, K. (January, 2016). Urban farming grows. Feeding Asia's City Dwellers. Asia Weekly. Retrieved Februrary 26, 2018 from http://asiaweekly.com/ growing-trend/
Wolf, K. \& Rozance, M. (2013). Social Strengths A Literature Review. In: Green Cities: Good Health. College of the Environment. University of Washington. Retrieved December 13, 2017 from https://depts.washington.edu/hhwb/Thm_ Community.html

Woolley, H. \& Rose, S. (2003). The value of Public Space. How high quality parks and public spaces create economic, social and environmental value. CABE Space Strategic Partners. Retrieved December 12, 2017 from https://www. designcouncil.org.uk/sites/ default/files/asset/document/the-value-of-publicspace1.pdf

Yeung, Y. (1987). Examples of Urban Agriculture in Asia, Food and Nutrition Bulletin, Vol. 9 No. 2. Retrieved Februrary 27, 2018 from: http://archive.unu.edu/ unupress/food/8F092e/8F092E05.htm

10 ciudades latinoamericanas que se destacan por la agricultura urbana. (2014). Agronoticias América Latina y el Caribe. Retrieved January 4, 2018 from: http://www.fao.org/agronoticias/territoriosinteligentes/noticias/detalle/es/c/225093/ 